EASTERN EUROPEAN JOURNAL OF TRANSNATIONAL RELATIONS

2017 Vol. 1 No. 1

DOI: 10.15290/eejtr.2017.01.01.02

Gracienne Lauwers ${ }^{1}$

Free University of Brussels

\title{
The Erasmus+ EduLAw Project for Strengthening Rights-based Education
}

\begin{abstract}
The purpose of the article is to explore the relevance of the EduLAw (ELA) project on law modules for teacher training courses, illustrated in the case study of the legal developments in the Flemish Community of Belgium.

The article analyses this issue by addressing two key points: firstly, it explains the background and relevance of the EduLAw project and recent European developments; secondly it illustrates how policymakers of the Flemish Community of Belgium have responded through public law to demands for stricter review of decisions about individual pupils of teachers, school principals and school boards on issues such as discipline and special needs requests. A short description of the relevant characteristics of the education system in the Flemish Community of Belgium, is followed by an examination of two 2014 decrees on education and their innovative response to demands for more transparency and legal certainty in rights-based decision making about pupils by teachers, school officials and school boards.

The analyses reveal that educational reforms are increasingly linked with the political cause of equality (Groof, Fussel, \& Lauwers, 2008, p. 223) and transparency in decision making of administrations, including school officials, especially decisions affecting the rights of individual pupils in education. Public law is thereby used to build in constraints as to how school autonomy and discretion of teachers, school officials and school boards should be exercised. The analyses also reveal the link between substantive requirements of good decision-making and procedural requirements. Procedural obligations in their turn opened the way for more substantive control by the court in disciplinary procedures, and enrolment of pupils with special education needs. The article concludes that, although schools still have autonomy to fashion their own school regulations, it is clear that the two decrees have, through procedural requirements and substantive principles of administrative legality, intruded into this
\end{abstract}

1 Professor at the Free University of Brussels (BE), Vytautas Magnus University (LT), University of Trento (IT), coordinating grant holder of the project ERASMUS+ Application (573540-EPP1-2016-1-BE-EPPKA2-CBHE-JP. E-mail: glauwers@me.com. 


\section{EASTERN EUROPEAN JOURNAL OF TRANSNATIONAL RELATIONS}

area. Thus, these changed circumstances require teachers, school principals and school boards to be trained in rights-based decision making. This is what the EduLAw is trying to accomplish.

Keywords: EduLAw (ELA) project; law modules for teacher training programs; autonomy of schools; rights-based decision making in education

\section{The EduLAw project background and underlying assumptions}

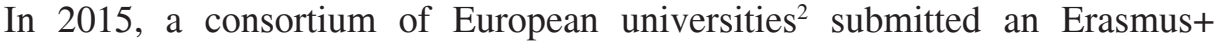
application on law modules for teacher training courses ${ }^{3}$. The underlying assumption was that collaboration between educators and lawyers is needed to promote effective teaching, learning, school leadership, and educational innovation. The project's indirect aim was to increase good lawyer-educator collaboration to improve decision making in education.

What are the trends in law and education that make effective collaboration increasingly necessary? In democratic societies, there is a growing need for such collaboration. Many court decisions introduced by individual students or staff members are held to reduce the discretion of educators and school leadership. Therefore, an effective collaboration between educators and lawyers is increasingly needed in central decision making on such educational matters as school governance, school reform, equality of educational opportunity, school leadership, and allocation of scarce resources (Heubert, 1997).

In contrast with this phenomenon and needs, the applicants found a lack of learning and teaching tools on education law and rights in education, as well as methodologies and pedagogical approaches and ICT-based knowledge testing on education law for professionals in education. Many teachers, school principals, school boards and lawyers are not engaged in ongoing collaboration while available learning tools in the discipline of education law was limited. Interdisciplinarity

The ERASMUS+ Application (573540-EPP-1-2016-1-BE-EPPKA2-CBHE-JP 'Introducing Modules on Law and Rights in Programmes of Teacher Training and Educational Sciences' was submitted with the consortium including Vrije Universiteit Brussel, Vytautas Magnus University, University of Bialystok, European Association for Education Law and Policy, University of Tirana, Aleksander Moisiu University of Dürres, Francisk Skorina Gomel State University, Belarusian State Pedagogical University, Moscow City University, Kutafin Moscow State Law University, Mari State University, Northern (Arctic) Federal University named after M.V. Lomonosov, National Research University Higher School of Economics. See: http:// edulaweu.eu \& https://www.youtube.com/channel/UCZXUc4iZZ63S1ityarIm_Tg (visited July 12, 2017).

3 The ERASMUS + Application (573540-EPP-1-2016-1-BE-EPPKA2-CBHE-JP) will be implemented in 2016-2019. 
could however not only improve lawyer-educator interactions, but could also reduce litigation in educational issues, while professionals in education could learn how to use the law to support and advance education policy objectives.

\section{Relevant developments at the European level}

The Lisbon Treaty ${ }^{4}$ rendered the Charter of Fundamental Rights of the European Union legally binding. Member States are bound by the Charter when implementing Union law, for example when a Member State implements a directive (European Parliament v. Council, 2006) ${ }^{5}$. Member States have an obligation to implement directives, and thus if the choice of form and methods are felt to violate a Charter right then this should be capable of being raised in the national courts which are also subject to the injunction to respect, observe, and promote the application of Charter rights.

Some of the Charter articles are of special relevance for decision making in education. The right to education is covered in Article 14 of the Charter. It imposes a substantive obligation, inter alia, on private institutions, even though the general field of application of the Charter is limited to Union institutions and Member States when implementing Union law. This tension might be reconciled by allowing an action to compel a public body to ensure that the private institution complies with the obligation contained in this article because Member States are bound by the Charter when implementing Union law which includes national courts irrespective of whether the case before the national court involves a public education authority or not.

Equality has seven articles in the Charter and is especially relevant in combination with Article 24 on children's rights and Article 26 on the integration of persons with disabilities. The webpage of DG Justice contains the actions taken by the Union to protect the rights of the child: 'Protection and promotion of the rights of the child is one of the objectives of the European Union. All policies and actions with an impact on children must be designed, implemented and monitored in line with the best interests of the child" ("Rights of the child," n.d.). Article 24, concerned with the protection of children, is said to be based on the New York Convention on

4 On 13 December 2007, the EU member states signed the Lisbon Treaty. It entered into force on 1 December 2009.

5 In the Case C-540/03 European Parliament v. Council the Court ruled that Directive 2003/86/ EC imposes precise positive obligations on the Member States. In the case that the Directive leaves the Member States a margin of appreciation, they should apply the rules of the Directive in a manner consistent with the requirements flowing from the protection of fundamental rights (23) and the Court will review the legality of national legislation implementing the Directive (22). The Court recalled that implementation of the Directive is subject to review by the national courts (106). 
the Rights of the Child 1989, which had been ratified by the Member States. It seems that the provision within the article that children may express their views freely could affect the legality of Union or state action. The right might not generate legislative competence, but might well require some positive action by Union and/or Member State authorities to safeguard the right in question.

Article 21 of the Charter bans discrimination on the ground of sex, race, colour, ethnic or social origin, genetic features, language, religion or belief, political or any other opinion, membership of a national minority, property, birth, disability, age or sexual orientation. This list of grounds is not exhaustive.

That brings the article to education reforms in the Flemish Community in Belgium triggered by the fundamental rights developments at the European and international level and linked with the political cause of equality and rights based decision making of teachers, school principals and school boards. In the wake of these developments, two 2014 decrees responded to demands for more transparency and legal certainty in decision making by school officials in issues affecting the right to education of individual students.

\section{The case of the Flemish Community of Belgium: characteristics of the educational system}

Belgium has constitutionally ${ }^{6}$ discharged its obligation to guarantee the right to education to a great extent to denominational schools (Groof, 1983). The Flemish Community of Belgium has a long standing tradition of school autonomy and pedagogical freedom with over $65 \%$ fully state funded denominational schools (Statistisch jaarboek van het Vlaams onderwijs schooljaar 2013-2014, 2015).

This tradition has led to rather informal school management. Schools were for decades governed by nonstatutory rules and regulations issued by the schools within their school autonomy and the constitutional freedom of education (see European Commission, n.d.).

Although decision-making in schools has always been subject to the application of the principles of good governance, in the context of changed societal values, state interference in school autonomy, led to statute law on decision-making on enrollment, inclusive education of pupils with special needs, examination disputes and temporary or permanent expulsion. The legislator of the Flemish Community of Belgium has now determined for all schools procedural and substantive requirements including proportionality, equality, transparency and legal certainty in decision making on issues directly affecting the right to education of pupils.

Article 24 of the Belgian Constitution. 
Two important $2014^{7}$ decrees, the M-decree (Decreet betreffende maatregelen, 2014) and the Decree on the Legal Status of Pupils (Decreet houdende diverse maatregelen betreffende, 2014), led to new forms of law-based reasoning through mandatory provisions to be clarified by schools in the school regulations (Flemish Children's Rights Commissioner's Office, 2015) ${ }^{8}$. These education reforms were triggered by the fundamental rights developments at the International (Lauwers, 2012) and European level (see Groof \& Lauwers, 2003; Lauwers, 2006).

Hereunder, both 2014 decrees and their innovative response to demands for more transparency and legal certainty in decision making by school officials in issues affecting the right to education of individual students will be examined briefly: how did the two decrees of 2014 actually amended decision making on individual pupils in schools (Decreet houdende diverse maatregelen betreffende, 2014), what concrete message did these decrees contain for school officials, how do these decrees serve as a meaningful instrument for discussions about the protection of the rights of pupils?

\section{Reforms in the Flemish Community of school sanctions, expulsion and procedural guarantees for pupils and parents}

Expulsion, long-term suspension or refused enrollment, can have considerable impact on a student's life. In the case of expulsion, the school may be acting in a quasi-judicial capacity, because it is taking decisions that affect the rights of students. In this quasi-judicial capacity, the school has to enact fair procedures and respect statutory obligations.

Unless exceptional circumstances are applicable in which a school may lawfully impose immediate long-term suspension without notice or procedures, e.g. where there is danger to life and property, fairness and validity of a school's suspension and expulsion procedures should be respected and can then later be challenged before the court in accordance with the provisions and procedures laid down in law of the Flemish Community of Belgium.

Under the 2014 Decree on the Legal Status of Pupils, schools have a legal obligation to afford the parents of a pupil or the pupil a hearing at the investigation which may result in the suspension or expulsion of their child from school. In addition, it was legislated that the functions of the school involve the obligation to follow specific procedures (Besluit van de Vlaamse Regering houdende, 2010, art.

7 The M-decree for special education needs children entered into force in the school year 2015/2016.

8 The summary report focusing on the situation of refugee children, children from Roma and Traveller families, and children with disabilities was prepared in view of the visit of the Commissioner for Human Rights for the Council of Europe to Belgium in September 2015. 
123/12, para. 1). Otherwise the validity of the school's decision could be challenged in court.

These procedures include an appeal commission. The decision of permanent exclusion can now be challenged under a special remedy appeal procedure. The composition of an appeal commission may vary for each case, but cannot be changed within the same case. The composition includes 'internal members' from the school and 'external members', i.e. people who are external to the school (Besluit van de Vlaamse Regering houdende, 2010, art. 123/13, para. 2). The school determines its operation, including the voting procedure but each member of the appeal commission has only one vote (Besluit van de Vlaamse Regering houdende, 2010, art. 123/13, para. 3). The appeal procedure is laid down by the school authorities in the school regulations. The provisions now clearly establish a mandatory procedure to be followed by the school and the parents who have to approve the school regulations by signing them when they enroll their child in the school (Besluit van de Vlaamse Regering houdende, 2010, art. 123/12, para. 1).

A person starts the appeal through a signed and dated application that at least states the subject of the appeal and includes a factual description and justification of the objections invoked. The appeal is heard by the appeals committee and leads to either the rejection of the appeal as inadmissible if the deadline for submission of the appeal in the school regulations, was not respected or if the action does not meet the formal requirements laid down in the school regulations. If admissible, the appeals committee can confirm the exclusion or annul the exclusion. The appeals commission (Besluit van de Vlaamse Regering houdende, 2010, art. 123/13, para. 1) will have to satisfy itself that the suspension or expulsion arrangements complied with the law and with the school regulations. It has to hear a contradictory account of the material incident. The decision is binding upon the school. The decision has also to mention the appeal procedures open to the pupil.

Although the substance of school discipline remains with the school authority, it is clear that the appeal commission and later the court could intervene where fairness has been denied.

In this way, legislation and case law have sought to balance between justice to pupils in trouble and justice to the school as a functioning unit. The school regulations should now elaborate a progressive disciplinary measures continuum (Besluit van de Vlaamse Regering houdende, 2010, art. 123/8) with expulsion as the last resort. Although schools still have a wide margin of decision making, safeguards to the right to education in disciplinary procedures are now firmly established in the law and the school has a statutory obligation to clearly communicate about the school regulations.

In conclusion, the 2014 Decree on the Status of Pupils in the Flemish Community of Belgium has been 'framing' the space left for school autonomy to be exercised by teachers, school principals and school boards in disciplinary procedures. The 
legislator has kept flexibility and choice inherent in school autonomy. However, uncertainty was resolved with regard to the wide discretion and informality in decision making in disciplinary matters. Only in these exceptional cases which the legislature perceives to go to the heart of the right to education of the individual pupil, did it no longer feel constrained by the constitutional freedom of education and did it adopt a strongly individual rights protection position, if need be in disregard of the wide appreciation that especially denominational schools traditionally enjoyed in the Flemish Community of Belgium.

\section{The reforms of the M-decree (Measures-decree for special education needs children)}

Till the not too distant past, the experience of many pupils with disability or special education needs in the Flemish Community in Belgium has been one of exclusion from mainstream education because the law permitted the segregation of pupils with disabilities from mainstream education (Groof \& Lauwers, 2003).

In recent decades, however, the law in the Flemish Community in Belgium has been playing a significant role in educational reforms for mainstream education by enacting anti-discrimination legislation to safeguard the rights of pupils with disabilities to varying degrees ("Van segregatie naar inclusie," n.d.). Pupils with special education needs now have rights in regard to their special education needs and disability pursuant to education legislation and equality and disability legislation. According to the website of the European Commission 'For children with special needs, the entry into force in 2015/2016 of the Flemish 'M-decree' is a major step towards increasing inclusion in the mainstream system.' From September 2015, every child, including those with special needs, has the right to enroll in a mainstream school, provided this is possible with reasonable adaptations. Around 180 full-time staff specialising in special education provide support to teacher teams in regular education. Initial results show a greater proportion of students with special needs participating in mainstream rather than special education' ("M-Decree for special education needs children," n.d.).

Statutory duties under the M-decree fall on school officials to make provision for adequate support measures for pupils with special education needs (Ministry of Education, 2017). The integration of all pupils with special education needs in mainstream education is part of Flemish education policy where all children have a statutory right to special education, if they are deemed to require such following a medical examination (see Craane, 2015; De Vroey, 2016; Deschacht, 2015; Van der Spiegel, 2016). The M-decree provides a statutory right to education for pupils with disabilities together with grants for the integration of children with disabilities into mainstream schools ('mainstreaming') and confers a right on all children 
with disabilities, no matter how profound or severe their handicap, to an education in a mainstreaming school unless this would required unreasonable measures. A specialist team should draw up an Individualised Education Plan (IEP) and the child is then placed in an appropriate educational environment. If unhappy with the procedures followed or the outcome, parents may initiate administrative or judicial review proceedings. The law grants parents independent enforceable rights, which encompass the entitlement to an education in a mainstream school.

However, the implementation varies considerably as it requires the will of school officials and teachers to ensure the full commencement of this legislation. Inclusive education is significantly deeper than a simplistic view that all children should study in the same educational environment. According to the Committee on the Rights of the Child 'The manner and form of inclusion must be dictated by the individual educational needs' (General comment No. 9, 2007).

Finally, it is for the courts to be the guardians of enhancing the rights of pupils with special education needs. By linking the needs of pupils with special education needs to the equal protection safeguards embodied in equality legislation, national courts drew attention to the urgent requirement for comprehensive legislation for this group of children. As in other jurisdictions, there is a consensus that a balance needs to be struck between the rights of the child with special needs to a mainstream education and, inter alia, the rights of other children in the class to a relatively disruption-free education.

Still, the M-decree has the potential to make a unique contribution to the rights of pupils with special education needs in every school. The important element for change in rights-based decision making at school level is the pupil-centered holistic view defined in the decree. It is, therefore, a useful and essential building block for education reforms aimed at strengthening the right to equal education opportunities for every child.

\section{Conclusion}

Decision-making by school officials, teachers and school principals, increasingly involves a kind of legal reasoning. Moreover, the principle that schools should be autonomous in many areas of their management had become accepted nearly everywhere in Europe. Learning how to make determinations in decisions directly affecting the right to education of individual pupils should therefore become a part of the training of school principals and teachers, and a substantial component of practice of managers of educational institutions.

In an effort to address this problem, the Erasmus+ EduLAw on law modules for teacher training courses was submitted and approved in 2016 by the EACEA Agency of the European Union. 
This article illustrates the impact of this trend in the Flemish Community of Belgium. The trend from a rather informal school management of schools governed by nonstatutory rules and regulations issued by the schools within their school autonomy and the constitutional freedom of education thereby respecting the application of the principles of good governance, towards state interference with the two decrees of 2014, reflect the context of changed societal values. The legislature has now determined for all schools procedural and substantive requirements including proportionality, equality, transparency, discretion and legal certainty in decision making on issues that touch directly on the right to education of pupils with mandatory provisions to be clarified by schools in the school regulations imposed through the 2014 decrees, the M-decree and the Decree on the Legal Status of Pupils.

This analyses reveals that the ever growing school autonomy has probably come to an end. Educational reforms are increasingly linked with the political cause of equality and transparency in decision making of administrations, including teachers, school principals and school boards, especially decisions affecting the right to education of individual pupils. Public law is thereby used to build in constraints as to how school autonomy and discretion of teachers, school principals and school boards should be exercised.

This article also reveals the link between substantive requirements of good decision-making and procedural requirements. Procedural obligations in their turn open the way for more substantive control by the court in disciplinary, enrolment and examination issues. It concludes that, although schools still have autonomy to fashion their own school regulations, it is clear that the recent decrees have through procedural requirements and substantive principles of administrative legality intruded into this area.

In this regard, particular account shall be taken of the principles of good governance, including proportionality in implementing decision-making in enrollment, disciplinary and examination matters. Schools had to review their procedures in the light of the $2014 \mathrm{M}$-decree. At the same time, schools took action and specified the procedure and their view on progressive disciplinary measures in the light of the 2014 Decree on the Legal Status of Pupils.

Still, much remains to be done. School principals and authorities have to demonstrate the will to give the most possible to develop schools in the spirit of both decrees. Also, the competence of teachers, school principals and school boards is paramount which in turn requires that they are trained accordingly.

This is probably a key point. Both decrees were developed in the best interests of the pupil but in order to sustain fundamental rights-based schools, teachers, school principals and school boards should make it 'do-able'. The legal obligation to clearly express their views in the school regulations should also mobilize the determination to make it happen and to move towards a school in the spirit of the decrees. 


\section{EASTERN EUROPEAN JOURNAL OF TRANSNATIONAL RELATIONS}

To conclude: it could be maintained that the preoccupation with the legitimacy of decisions of teachers, school principals and school boards and authorities is a peculiarity of the 21 st century phenomenon that increasingly features within the academic or judicial discourse. Teachers, school principals and school boards should at the very least be aware of the changed circumstances in which the right to education is adjudicated and should be trained in rights-based decision making.

\section{REFERENCES}

Besluit van de Vlaamse Regering houdende de codificatie betreffende het secundair onderwijs [Codex Secondary Education] (2010). B.S.24/06/2011. Retrieved from https://data-onderwijs. vlaanderen.be/edulex/document.aspx?docid=14289\#308272

Craane, T. (2015). Het M-decreet onder de loep genomen (Master thesis). Universiteit Antwerpen.

De Vroey, A. (2016). Inclusive practices and co-support in Flemish secondary schools. A qualitative study on inclusive school development (Doctoral thesis). University of Leuven.

Decreet betreffende maatregelen voor leerlingen met specifieke onderwijsbehoeften (2014). B.S.28/08/2014.

Decreet houdende diverse maatregelen betreffende de rechtspositie van leerlingen in het basis- en secundair onderwijs en betreffende de participatie op school (2014). B.S.20/08/2014.

Deschacht, B. (2015). Onderzoek: inclusief onderwijs en $M$ - decreet: realisatie bij leerkrachten.

European Commission. (n.d.). Education and Training Monitor 2016 Belgium. Retrieved from https:// ec.europa.eu/education/sites/education/files/monitor2016-be_en.pdf

European Parliament v. Council, C-540/03 (2006). ECLI:EU:C:2006:429.

Flemish Children's Rights Commissioner's Office. (2015). Report on children's rights for specific groups in Flanders (pp. 1-15). Brussels. Retrieved from https://www.kinderrechtencommissariaat.be/ sites/default/files/bestanden/prepkrc4muiznieks_15_09_2015.pdf

General comment No. 9 (2006): The rights of children with disabilities (2007). CRC/C/GC/9. Retrieved from http://www.refworld.org/docid/461b93f72.html

Groof, J. D. (1983). Recht op en vrijheid van onderwijs. CEPESS.

Groof, J. D., Fussel, H.-P., \& Lauwers, G. (Eds.). (2008). Inequality in Education. Nijmegen: Wolf Legal Publishers.

Groof, J. D., \& Lauwers, G. (Eds.). (2003). Special Education: Yearbook of the European Association for Education Law and Policy. Springer Netherlands. Retrieved from //www.springer.com/gp/ book/9781402015458

Heubert, J. (1997). The More We Get Together: Improving Collaboration between Educators and Their Lawyers. Harvard Educational Review, 67(3), 531-583. https://doi.org/10.17763/ haer.67.3.595072k230471549

Lauwers, G. (2006). De bewijslast in het geval van segregatie in het onderwijs volgens het Europees Hof voor de Rechten van de Mens. Tijdschrift voor onderwijsrecht en onderwijsbeleid, (3), $143-152$. 


\section{THE ERASMUS+ EDULAW PROJECT FOR STRENGTHENING...}

Lauwers, G. (2012). Deel 2 van het advies op de Implementatie van het VN-verdrag voor personen met een handicap: advies Steunpunt Recht en Onderwijs. In opdracht van het Ministerie van de Vlaamse Gemeenschap.

M-Decree for special education needs children. (n.d.). Retrieved July 12, 2017, from https://ec.europa. eu/education/compendium/m-decree-special-education-needs-children_en

Ministry of Education (of the Flemish Community of Belgium). (2017). Interim metaevaluation of the M-decree. Retrieved from http://onderwijs.vlaanderen.be/nl/ tussentijdse-meta-evaluatie-m-decreet

Rights of the child. (n.d.). Retrieved July 12, 2017, from https://ec.europa.eu/info/strategy/ justice-and-fundamental-rights/rights-child_en

Statistisch jaarboek van het Vlaams onderwijs schooljaar 2013-2014. (2015). Retrieved from http:// ebl.vlaanderen.be/publications/documents/69187

Van der Spiegel, R. (2016). De rol en positie van ouders binnen incusief onderwijs voor de invoering van het M-decreet (Master thesis). Universiteit Antwerpen.

Van segregatie naar inclusie [From segregation to inclusion]. (n.d.). Retrieved July 12, 2017, from /nl/ grote-lijnen-van-het-m-decreet 